\title{
Understanding 'Hall-Houses': debating Seigneurial buildings in Ireland in the 13th Century
}

Article

Accepted Version

Dempsey, K. (2017) Understanding 'Hall-Houses': debating Seigneurial buildings in Ireland in the 13th Century. Medieval Archaeology, 61 (2). pp. 372-399. ISSN 0076-6097 doi: https://doi.org/10.1080/00766097.2017.1375183 Available at https://centaur.reading.ac.uk/74345/

It is advisable to refer to the publisher's version if you intend to cite from the work. See Guidance on citing.

To link to this article DOI: http://dx.doi.org/10.1080/00766097.2017.1375183

Publisher: Maney Publishing

All outputs in CentAUR are protected by Intellectual Property Rights law, including copyright law. Copyright and IPR is retained by the creators or other copyright holders. Terms and conditions for use of this material are defined in the End User Agreement.

$\underline{\text { www.reading.ac.uk/centaur }}$ 
Central Archive at the University of Reading

Reading's research outputs online 
THE SEIGNURIAL HALL and chamber have been assumed, in both Britain and Ireland, to be typically located in the only building to generally survive on medieval residential sites. In England this idea has seen some revision, but in Ireland there has been little recent scholarship on medieval residential spaces. As a consequence, the term 'hall-house' is still used by Irish scholars as a label for some two-storey, 13th-century buildings, providing both a description and interpretation. The inference is that these buildings acted as both halls and elite residences at the same time during the High to Late Middle Ages. This contradicts what we know of the complex social codes of the time. Drawing on new empirical research, this article challenges the 'hall-house' classification, and explores different ways in which the spaces of these Irish medieval buildings can be better understood.

\section{INTRODUCTION}

The masonry structures which are the focus of this article all belong to a distinct type of seigneurial dwelling that was popular in Ireland from AD 1200-1260 (Fig 1). They have, until recently, been described as 'hall-houses'. ${ }^{2}$ These masonry buildings typically comprised a rectangular two-storeyed structure with a first-floor entrance that provided access into an apparently open plan space which was believed to have functioned in the same manner as a medieval hall, while also operating as a residence. ${ }^{3}$ It was assumed that these buildings were typically isolated, without associated structures in their immediate environment. ${ }^{4}$ Investigation of the architecture and interior spaces of these 'hall-houses' and their landscape context, has provided a new understanding of this building type and revealed the problematic nature of many pre-existing assumptions.

\section{BACKGROUND}

A short article by Tom McNeill introduced the term 'hall-house' to Ireland in the early 1990s as a label for these storeyed, high medieval buildings. ${ }^{5}$ While this should have sparked a long conversation about domestic planning in medieval Ireland, instead the 'hall-house' was accepted as a classification and became so firmly established that it formed an entire chapter in Tom McNeill's Castles in Ireland. By 1999, the 'hall-house' had become a prolific monument type, due to David Sweetman's listing of over 40 examples from across nine counties. ${ }^{6}$ In conjunction with this, 'hall-house' was coined as an official 'classification' in Ireland and widely employed by the Archaeological Survey of Ireland who operated under Sweetman's direction. The online Archaeological Survey of Ireland now lists 47 examples in the Republic of Ireland (see Fig 2).

The 'hall-house' model has continued in use. For example Rory Sherlock published a paper on the domestic planning of late-medieval tower-houses, in which he assumed the accuracy of the 'hall-house' model, ${ }^{7}$ arguing that 13 th-century buildings could be the typological predecessors of 15th/16th century late-medieval tower-houses. He suggested that like the earlier 'hall-houses', tower-houses contained halls which functioned as public and ceremonial spaces, and that these could be placed interchangeably above or below the principal private chambers. Tadhg O'Keeffe has responded with the observation that halls and chambers might not be spatially interchangeable in medieval culture, ${ }^{8}$ suggesting that neither tower-houses nor 
'hall-houses' contained 'public' spaces (in the sense of places of seigneurial communal gathering and feasting or administration). In his view both types of building were likely residential spaces that only contained private rooms. O'Keeffe has argued that the misconception has arisen through reliance on Sweetman's suggestions that 'hall-houses' were buildings with public functions. Geoffrey Stell has since claimed that the Scottish evidence has been similarly been misread, ${ }^{9}$ while Gillian Scott (neé Eadie) has posited that tower-houses were private spaces with external halls, as exemplified at Aughnanure Castle, Co Galway. ${ }^{10}$

These papers, come at the end of a period of intense study on the hall and chamber in Britain and France in the 1990s and early 2000s. ${ }^{11}$ In particular, a colloquium on Norman domestic planning organised by John Blair, Michael Jones and Gywn Meirion-Jones, resulted in arguments by Blair that the 'first-floor hall' was an inappropriate model of interpretation for domestic planning in Britain in 12th- and 13th-century manorial buildings, and that most storeyed buildings were in fact chamber-blocks that were once accompanied by a, now lost, ground-floor hall. ${ }^{12}$ His argument was subsequently corroborated by work at Boothby Pagnell, Lincolnshire, a high-status manor house that had once been the exemplar of the 'first-floor hall' model in England. ${ }^{13}$ This site was revisited, and geophysical survey revealed the potential for an associated ground-floor hall, as Blair had suggested. This was confirmed by excavation, which not only revealed the structure of the associated ground-floor hall, but also a substantial amount of contemporary material culture that one would expect to be associated with a communal feasting and administrative space. ${ }^{14}$ Significantly, the buildings described as upper halls in England and France (pre 1225), appear remarkably similar to the 'hall-houses' of Ireland, suggesting that interrogation of Blair's theory in relation to Irish evidence was overdue. ${ }^{15}$

As a starting point, a systematic analysis of all 13th-century seigneurial buildings was required, not just those labelled as 'hall-houses'. Once this had been achieved, other issues could be explored including function. Questions could be posed such as, were these halls or houses? If they were halls, why were they different to those buildings understood as halls in contemporary parts of Norman England? If they were not halls, and were in fact chambers, like similar buildings in England, why were they still being described in Ireland as 'hall-houses'?

This article sets out to answer some of these questions. Initially the general characteristics of seigneurial buildings are explored in order to better understand their distribution and typical architectural attributes, including shape and size, as well as internal and external features. Rather than recounting all details, key attributes are discussed with a view to particularly understanding the arrangement of space. This evidence is reviewed first and then used to aid discussion of the internal arrangements or social space of these buildings.

At the outset, it is important to state that the terms 'castle' or 'manor-house' are deliberately avoided in this paper unless specific to certain buildings. These are additional issues that need separate exploration as part of a broader debate. It is sufficient to say that the buildings discussed in this paper are seigneurial and that they belonged to various ranks within the complex and hierarchical society of 13th-century Ireland.

\section{NUMBER AND DISTRIBUTION}

During the course of this study, 87 buildings were identified through field survey as structures containing features that would ascribe them to the 'hall-house' class; only 37 of these are officially classified as 'hall-houses' by the National Monuments Survey of Ireland. This type of building is primarily associated with the province of Connacht, in the west of Ireland, and has been considered instrumental in the Anglo-Norman colonisation of the area c $1236 .{ }^{16}$ This interpretation is related to the overly-simplistic idea that mottes were only constructed in 
eastern and south-eastern Ireland, as territorial controls during the 12th-century settlement of the province of Leinster, some 50 years before the Anglo-Norman colonisation of Connacht Fieldwork has subsequently revealed many similar buildings to the 'hall-houses' of Connacht in other parts of Ireland. Concentrations are now recognised in Co Tipperary (19) and Co Limerick (9), with smaller pockets in Co Kildare (5) and Co Cork (4). It is possible that more remain to be identified, especially in areas where they appear to be absent, perhaps incorporated in latemedieval buildings such as tower-houses, or demolished as part of past agricultural clearance of land and quarrying for building material, or erased through development in highly urbanised and industrial localities like Dublin. ${ }^{17}$ Nevertheless, the highest density can be found in the province of Connacht, occurring in large numbers in Co Galway (20) and Co Mayo (15), and to a much lesser extent in Co Roscommon (5). In counties Tipperary, Galway and Mayo, these seigneurial buildings cluster closely together in certain areas suggesting they were either the baronial caput, or in a territory adjacent to it. In the latter two counties, they particularly occur around the lakes at Lough Corrib, Lough Mask, and to a lesser degree Lough Cara. In contrast, these buildings have a highly dispersed distribution across the county of Limerick, with one or two placed in each cantred, presumably acting as the caput of that area.

\section{ARCHITECTURAL OVERVIEW}

\section{SHAPE AND PROPORTIONS}

The 87 buildings identified are remarkably homogenous and typically conform to a particular format: a rectangular-shaped structure with a base-batter (a large sloping protrusion from the base of the building's wall varying size). In all instances, a now lost timber stair provided access to the main entrance at first-floor level and a large open space lit by a number of openings, presumably once windows. This level also had a spatially demarcated latrine (discussed below). Fourteen buildings were too ruined to decipher anything more from the remains beyond a basic shape. Of the remainder, 49 were originally two-storey, and 39 of these had a later floor inserted, primarily within the roof space (there are exceptions to this such as at Kinlough and Dunmore in Co Galway (Fig 3) where the wall-height was augmented at a later date). Twenty-four of the towers were likely to originally have been three-storeys in height, and 13 of these had a further floor inserted at some point.

Many authors have stated that 'hall-houses' have proportions approaching 2:1, giving a structure that is twice as long as it is wide. ${ }^{18}$ This survey has demonstrated that there are no standard proportions for these buildings: only 23 out of 87 have dimensions that lie close to this ratio. The buildings with more than two storeys, such as Shrule, Co Mayo ( $15 \mathrm{~m} \times 11 \mathrm{~m}$ ), are inclined to have a more traditional turriform appearance; their dimensions provide evidence of a squarer shape, evident for example if Shrule is compared to Annaghkeen in the same county (16 $\mathrm{m} \times 10.4 \mathrm{~m}$ ) (Fig 1). There are also a small number of elongated, rectangular two-storey buildings that have a very long axis when compared to their width, such as Tomdeely, Co Limerick (20.6 m x $10.6 \mathrm{~m}$ ), or Castle Conor, Co Sligo (18.6 m x $10.6 \mathrm{~m})$. These variations in shape and height suggest that the spatial arrangement of 'hall-houses' comprised either vertically stacked or horizontally extended 'rooms' depending on the desires of those who owned or lived in them. . 
Despite the homogeneity evident in these buildings, there are also indications of patronal tastes. Further to the slight variations in size discussed above, two small groups of buildings show particularities that can only be considered as stylistic: these include the use of clasping pilasters (or buttresses) of varying sizes and structures that have chamfered corners (see Fig 4). The former have been discussed in press elsewhere, and so chamfered corners are the focus here. ${ }^{19}$

There are only eight known examples of buildings that employ this feature in this time period in Ireland, and these are spread across a wide geographic area: Ballyderown, Co Cork; Grenan, Co Kilkenny; Corraun, Co Longford; Tomdeely, Co Limerick; Clohaskin, Co Tipperary; and Shrule, Castlemagarret and Ballycurrin in Co Mayo (Fig 4). Typically, the chamfer begins just above the base-batter and finishes at, or below, the roof line, but they vary in size. Ballyderown, Grenan, and Corraun have a very slight chamfer, no more than $20 \mathrm{~cm}$ in width. In contrast, the others, apart from Ballycurrin have very wide chamfers, over $60 \mathrm{~cm}$ in some cases. Ballycurrin contains only one chamfer located at the south-western end of the building (see Fig 8), perhaps due to the collapse of the western end, although the remaining corner at the east end is not chamfered. Tomdeely also has a hint of the end of an arrow loop, where the top of the chamfer corner has now fallen.

Chamfered corners, unlike the corner pilasters - some of which were consistently associated with building developments by the de Marisco's family in Ireland ${ }^{20}$ - do not appear to be indicative of a formal or familial-linked group. Nonetheless, the limited number of examples suggests that this stylistic choice represented something that is now lost to us. Unlike the 'pilaster group', the patrons of buildings with one or more chamfered corners are largely unknown, apart from at Shrule, Grenan and Ballyderown. These buildings, however, feature infrequently in the historical record, and it is not possible to infer any familial connection with certainty. While such a design characteristic might be connected to the work of a specific group of travelling builders, it seems more likely that this feature reflected the choices and tastes of patrons.

\section{COMMON ARCHITECTURAL FEATURES}

Externally the most notable diagnostic feature of these buildings is the presence of a base-batter. Over 80 of the buildings share such a feature, and though many of these have been 'robbed out', in some cases, they remain remarkably intact. The surviving batters vary in size from those that are barely evident to some that rise to almost $2 \mathrm{~m}$ in height. There are rare examples that show no trace of a batter such as Longford, Co Galway and Simonstown, Co Westmeath, but these may be slightly later buildings, dating to the early 14th century.

Typically, these high medieval buildings have thick walls greater than $1.3 \mathrm{~m}$. Evidence, such as missing quoin stones, suggests that much of the stonework from these buildings has been lost. Where sufficient architectural detail remains, some universals are evident: elevated entrances at first-floor level over poorly-lit basements, and latrines constructed as chutes, machicolations or towers. Occasionally, there is evidence for crenellations such as at Kinlough, Co Mayo (see Fig 3).

Internally, common features include mural stairs, while fireplaces and mural chambers occur less frequently. Fenestration does not seem to have been of primary importance - there is no common arrangement or discernible patterning of window openings. In some cases, there is one embrasure in each wall and in others three walls have five between them in various formations. A small number of these buildings contain symmetrically opposed embrasures but 
this is rare. The majority of original windows were set in large round or segmental arched embrasures with either splayed or squared returns. There are examples of single-lights such as the lancet-like examples at Moylough, Co Mayo. Some windows must have contained twin-lights due to the sizes of the embrasures such as Lisbunny, Co. Tipperary.

Two characteristics appear consistently within these buildings and are frequently used as diagnostics in identifying a residential space in buildings from the Middle Ages: fireplaces and latrines. As latrines are the most common and obvious internal feature associated with the use of these buildings as a living space, they are dealt with first.

\section{Latrines}

There are 46 chambers with surviving remains of latrines. The most common location for the placement of latrines was in the northern, north-eastern and north-western parts of the first-floor of these buildings, predominantly at a corner edge, opposing the main entrance doorway, either directly opposite or in the corner diagonally opposite. The latrine is usually located along the colder northern wall, while the main entrance to the chamber is often on the warmer and brighter southern wall. A latrine and a main entrance never occurred together along the same wall-face. Naturally, we can conclude that their positions influenced each other. Indeed, as we will see later, it seems apparent that the latrines were screened, in one way or another, from the main entrance, as one would expect. Externally, however, the architectural signature of the latrine was very visible.

Of those latrines that are visible, 33 out of a total of 46 , are contained within the built fabric, visible as either latrine chutes or as slightly overhanging features, positioned over the machicolation, held on corbels or beams of wood that once protruded from the wall. Thirteen are service towers, of which six are later in date. For machicolated latrines (13 out of the 46 known examples), waste dropped directly out from underneath the latrine, through a cavity, down the wall and onto the ground. It was assumed by Irish scholars that machicolated latrines were the most common type, however, this research demonstrates that latrine chutes are the most dominant form with 22 identifiable out of the sample of 46 . They perform the same function as a machicolated latrine, but the chutes channel the waste down to the base of the building in a more discreet fashion. Four of these medieval buildings contain latrine chutes that project very slightly from the wall face, eg Shrule (Fig 5).

Architecturally different to the mural chutes are the 'buttress' chutes that are contained within the immense masonry projections which clasped the sides of the buildings at Castle Carra and Castlemagarret (Co Mayo) (Fig 5). Interestingly, these two rare examples use the chutes to channel waste in an apparently discreet manner, while also architecturally emphasising the process. Latrine chutes are also found in purpose-built service-towers such as at Kindlestown, Co Wicklow. This service tower contained two latrines and a double chute with two separate exits (Fig 5). A latrine or service tower (13 out of 46 known examples), typically projects outwards from the building. The latrine itself was self-contained within a small chamber which no doubt gave the user more comfort. These service towers have a waste collection pit at the lowest level which needed to be emptied by someone, perhaps a further assertion of the power of owner. Interestingly, it was also possible for other rooms to be located above the latrines in these towers, and for these to have different uses. For example, at Annaghkeen, the latrine tower is three-storeys and the first-floor of this contains a latrine. The room above is now vaulted and the access to the space is not straightforward. The vault, the placement of the space over the latrine, and the relatively detailed access to it indicates that it was not a space foreveryone. 
There is great variance in the manner in which latrines were accessed from the first-floor space and there seems to be no apparent correlation between passage type and latrine. The wall thickness of the majority of these buildings was over $1.5 \mathrm{~m}$ in width (67 instances) and therefore able to accommodate mural passage to the latrines. In a small number of the more modest buildings such as Ballisnahyny, Co. Mayo and Kilskeagh, Co. Galway the passage to the latrine cuts straight through the wall beside a corner angle. There appears to be no room or evidence for a hinged door. However, it is likely that a screen or heavy curtain was placed in front of the passage, to separate the latrine from the chamber, if not for discretion, at least to shield the breeze which must have blown through the latrines. Other passages were right-angled, and access was gained through a narrow entrance from which the passage widened and narrowed again at the latrine. Examples of this are found at Dunmore and Athenry, both in Co Galway. A more intricate version of this approach, in evidence at Ballycurrin, contained two right-angle turns which resulted in a dog-leg shaped passage. A further variation of this was a sort of uneven U-shaped passage where two right-angled turns are taken before and after a corner, with the latrine passage entrance in one wall and the actual latrine in another, eg at Ballylusky, Co Tipperary. The access path to latrines tended to be short and Shrule and Tomdeely are exceptions to this (Fig 10). There are vaulted passages that contain evidence for plank centring, such as at Ballycurrin, but there are also flat-roofed examples, as at Shrule. There appears to be no common pattern or preference for passages to latrines.

There is no doubt that latrines were important features of these buildings. The many different types, their varied means of access, and their high visibility, all suggest that deliberate choices were made in their creation. Their construction, layout and means of access and use enabled these features to be both theatrical and discreet, often at the same time.

\section{Fireplaces}

Central hearths were a typical feature of medieval halls. Conversely, fireplaces (and toilets), are indicative of a space removed from public life - the chamber. Only 8 of the buildings in this study contained evidence for a fireplace. Whether this is indicative of a typically low number of fireplaces originally included in these buildings in the past is hard to say. What is certain is that these buildings needed heat, but perhaps rather than all of them containing fireplaces, the majority contained braziers - metal moveable fire stands which were common during the Middle Ages. ${ }^{21}$ As the majority of the buildings did not originally contain vaults, but were timber-floored, this may have been problematic. Perhaps, the moveable braziers were elevated on a block of masonry, or a metal tray, so that embers or sparks could not cause a fire. None of these buildings contained a central hearth.

Coonagh, a tenant-in-chief grand chamber, ${ }^{22}$ which is in a different hierarchical tier to most of the buildings in this study, contains evidence for a large, fireplace at first-floor level (Fig 6). It comprised ashlar blocks and was slightly recessed within the wall. Two large sockets are visible either side of the fireplace; these were likely to have been decorative corbels that supported or provided stability for a hood.

Relatively close to Coonagh (within the former medieval county of Munster) are Lisbunny and Tomdeely. Both are pre-1230 and thus close in date to Coonagh. Lisbunny contains an original fireplace beside a window located at first-floor level near the north-eastern corner (Fig 6). The fireplace was constructed in a square recess and a masonry funnel or hood channelled the smoke outwards. The fireplace comprises a large round arch with a keystone in the centre which is flanked by faced stone at the returns of the fireplace. At Tomdeely, the fireplace is 'robbed out', but still likely to be original. It comprised a slightly protruding hood and was 
constructed of the same coursed masonry as the rest of the building. It was narrow, set in a recess in the thickness of the wall, and located between two large window embrasures.

Shrule is somewhat later than the above examples (post-1235). The building was originally three-storeys. It potentially contained two fireplaces, one on the first and one of the second-floor levels (Fig 10). The second-floor level example is a square recess set in the thickness of the wall with a smooth finish which suggests it was not inserted. An arch supports the 'hood' of the fireplace which funnels the smoke upwards. Two stone corbels flank the fireplace and it is possible that they may once have supported a sort of mantle. The other fireplace at first-floor level is more tentatively identified because only a straight-sided opening remains. However, the position of this putative fireplace close to latrine, along the north wall, makes this suggestion somewhat more promising as these features are often proximate. Furthermore, two later chimneys indicate that Shrule once contained two flues, and thus likely contained two separate fireplaces.

Dunmore, which is of a similar date to Shrule, was the caput of the de Bermingham's lordship of Dunmore. ${ }^{23}$ It contained a large fireplace set centrally in the north wall directly opposite the main first-floor entrance (Fig 6). This was set within a square recess with a straight flue for the chimney. The fireplace surround is much 'robbed out', but its surviving shape suggests it once sported a large hood, most likely constructed from the same roughly coursed masonry of the building itself.

Apart from these possible hooded fireplaces, there are a number of other examples that may have been altered in the late-medieval period (post-1500) such as Castlemagarret and Castle Hackett. The fireplace at Castlemagarret is located in the western section of the first-floor space where it is recessed within the walls space and set beside a cut-stone window. This appears to have been subject to later alterations as there is evidence for patchwork in the outer and inner-face of the western wall in this area. At Castle Hackett, the fireplace is a later design, but it may have been placed in the location of the original example as there is no evidence for any internal or external alterations beyond the style of the fireplace.

Towards the end of the 12th century, the hooded fireplace began to appear in England. ${ }^{24}$ The fireplace was set in a recess (of varying widths) and the hood protruded slightly into the room. It rested on corbels and often contained a lintel. ${ }^{25}$ The buildings under discussion here contain fireplaces similar to English examples.

In the broader tradition of scholarship on Norman domestic planning, castle and buildings archaeology, similar buildings to those under discussion here, in closely related contexts, are no longer understood to contain halls at first-floor level. In Britain for instance, the term 'upper-hall' has lapsed from use in the last couple of decades. The evidence presented here suggests that the buildings described as 'hall-houses' in Ireland occur in greater numbers and have a wider geographic distribution than previously recognised. Having broadly discussed the architectural attributes of these buildings and highlighted the presence and location of latrines, the irregular fenestration, and the absence of central hearths at first-floor level, it is important now to reevaluate the 'hall' element of the descriptive and interpretative classification of the Irish 'hallhouse'.

\section{THE PROBLEM OF THE 'HALL-HOUSE'}

A medieval hall was a building which formed the focal point of an estate, a 'public' space for 'public' events centred on the mobilisation of lordly power. ${ }^{26}$ These events included feasting, legal and administrative activities such as holding manorial courts, paying homage to a lord, a place of assembly for the tenants, as well as a space for the lord, lady and familia. ${ }^{27}$ In the 
medieval period the concepts of privacy and its corollary, 'publicness', were not understood in the way we might interpret them today, however, it is certain that a medieval hall, understood as a place of feasting and administration, was not a residential space for the lord or lady. ${ }^{28}$ Secondly, the hall was a space belonging to one individual of authority. ${ }^{29}$ Thirdly, in terms of architecture, it was an open, well-lit space, with a central hearth designed to emphasize the communal theatre of medieval life.

In this examination of broad range of medieval castles and seigneurial buildings of varying ranks, it became very apparent that only a very small number of buildings dating from the 12th and 13th centuries in Ireland could be confidently identified as medieval stone-built halls on the basis of their proportions of 1:2, or on their ground-floor position and internal arrangements (services, paired windows, a 'high' and 'low' end). ${ }^{30}$ Such halls - all in stone belonged to tenant-in-chief castles such as Trim in Co Meath, Adare in Co Limerick or at Athenry, Co Galway, where they operated as one part of a larger, diverse complex of buildings. None of the so-called 'hall-houses' displayed characteristics that could be confidently associated with a medieval hall.

In Ireland, castles and seigneurial complexes below this rank are recognised as acting as estate centres, whether serving large baronies or smaller manors. Although little has been explicitly stated about the individual buildings that housed the administrative, residential and agricultural parts of these complexes, it is accepted that these included the hall and the chamber. ${ }^{31}$ Kieran O'Conor reviewed the historical evidence for such complexes in Medieval Rural Settlement in Ireland, outlining a number of documented manors composed of a variety of buildings, such as thatched halls, kitchens, chambers, granaries, chapels, fish-houses, dovecotes and outer enclosures including haggards. ${ }^{32}$ Similarly, McNeill endeavoured to identify a set format for Irish manorial complexes by analysing historical sources that outlined the contents of manorial centres, such as the well-known extent of Cloncurry in $1304 .{ }^{33}$ In his study, a number of features were identified as common to manors such as haggards, stone chambers, wooden halls, barns and granaries. McNeill stated that the historical sources 'give similar pictures of a collection of wooden buildings with the occasional stone chamber set within courtyards....These buildings are both strictly agricultural, such as barns, and seigneurial or residential such as the hall and chambers' ${ }^{34}$

This information highlights the reasons why the 'hall-house' is a problematic descriptive and interpretive category. ${ }^{35}$ Not only is the architecture of surviving buildings lacking in compelling evidence of features that might be indicative of medieval hall culture, the historical source material explicitly states in the 13th century in Ireland that the wooden hall and stone chamber were separate buildings within larger complexes. A further complication is the absence of much transnational comparison with similar structures in England and France; these Irish 'hallhouses' have largely been discussed in relation to each other. And yet these Irish buildings are remarkably similar to the contemporary 'upper-halls' in England and France, which are now understood as domestic and residential spaces. It seems it may no longer be appropriate to suggest that these buildings contained a high medieval hall. It is more likely, that they were in fact seigneurial residences of the Anglo-Norman period - the stone chambers that are recounted within the Irish historical sources.

In order to test this argument further, and in light of the re-analysis of Boothby Pagnell as a hall and chamber complex, geophysical survey (earth resistance) was employed by the author to test whether 'hall-houses' really were isolated structures, or if evidence could be provided for attendant buildings, one of which might be a timber-constructed medieval hall of the type discussed in the historical sources. It is important to acknowledge that masonry remains are only 
one part of a manorial complex - timber buildings as well as organic features, fixtures and fittings typically do not survive. ${ }^{36}$

GEOPHYSICAL INVESTIGATION

The methodological benefits of utilising geophysical survey, especially electrical resistivity, to establish the presence of sub-surface masonry remains at archaeological sites needs no explication, it is an established and respected method of investigation. After some consideration of locations and survival, three buildings that had typified the 'hall-house' paradigm were chosen: Ballisnahyny and Shrule, both in Co Mayo and Annaghkeen, Co Galway. ${ }^{37}$ Subsequently, two further sites, at Castlemore and Castlesampson in Co Roscommon, were selected for survey. ${ }^{38}$ Both of these have very visible earthworks and masonry remains as well as the surviving stone buildings. ${ }^{39}$ All the sites are located within townlands of the same name in areas of documented Anglo-Norman settlement. At the first three sites, resistivity was carried out. At Castlemore and Castlesampson two extra techniques were introduced: electro-magnetic and magnetometry survey. The survey areas ranged in size from $40 \mathrm{~m} \times 40 \mathrm{~m}$, to much more extensive coverage of $120 \mathrm{~m} \times 80 \mathrm{~m}$.

The geophysical surveys revealed that each site had clear evidence for an abundance of sub-surface anomalies (Fig 7). At Shrule, Annaghkeen, Ballisnahyny (Fig 7) and Castlesampson, a large rectangular feature was revealed close to the extant stone building at each site. At Shrule and to a lesser degree, Castlesampson, indications of internal divisions are present within the rectangular sub-surface structure. Except for Ballisnahyny, there was an indication of a central stone feature within the rectangular structure at each site. Interestingly, at Castlesampson and Castlemore, this central stone feature was also revealed as an area of magnetic susceptibility that is typically indicative of in situ burning. This may be suggestive of the presence of a central hearth. Other features included additional structures, possible metalled surfaces, and outer enclosures. It is not possibly to conclusively say that the sub-surface remains were contemporary with the medieval building. However, contextual evidence including the re-analysis of Boothby Pagnell, ${ }^{40}$ are suggestive that a storeyed chamber and ground-floor hall, set among associated buildings, was a typical arrangement for seigneurial complexes of the 12th and 13th centuries in England and France.

The original hypothesis that 'hall-houses' were manorial or estate centres because they lacked the stone chambers that historical accounts suggest were essential elements, now lies open to debate. ${ }^{41}$ The extant masonry structures that now remain, may be these 'missing' stone chambers, and instead it is the 'hall' that is the lost element of these complexes. The geophysical results demonstrate there is more to do to explore this idea: Castlemore and Castlesampson were clearly part of larger complexes with indications of outer enclosures as well as a significant number of sub-surface features. ${ }^{42}$ At contemporary castle sites such as Athenry, Co Galway, stone-built ground-floor medieval halls are present as well as a stone-built and storeyed structure that seems to have been the main residential space. While these belonged to higher status patrons, it seems plausible that manors or baronial complexes contained similar buildings. It is interesting to note, that the buildings investigated as part of this study were likely to have been either manorial or baronial capita, and therefore represented the cultural, ceremonial and administrative centres of each relevant territory.

Analysis of historical sources combined with landscape survey and geophysical prospection, together indicate that many of these complexes were likely to have been surrounded by an enclosure - a haggard, earthen or stone wall. Geophysical survey at Castlesampson revealed an extensive outer enclosure. Slight traces of extant earthen enclosures are also present at Grenan in Co Kilkenny, Castlemagarret in Co Mayo and Clohaskin, Co 
Tipperary. ${ }^{43}$ Others such as Ballykine and Ballisnahyny, Co Mayo, were built into an earlier earthwork. An enclosure was important way of marking out the space in a building complex. Interestingly, the geophysical survey at Annaghkeen revealed evidence for a potential paved area, possibly representing a courtyard, around which other structures were organised. An early 20th century re-telling of an antiquarian account stated that Grenan Castle, Co Kilkenny was once situated within an enclosure that contained a possibly original, paved courtyard, unfortunately now destroyed. ${ }^{44}$ Many of these enclosed areas may once have been cobbled, paved or at the very least metalled, to enhance the spatial authority of the complex and emulate their contemporary castle counterparts.

Based on this new evidence, the 'hall-house', if understood as an isolated structure with a hall-cum-chamber at first-floor level, is no longer valid as a single descriptor and interpretative model. The cumulative results suggest that it is far more likely that the buildings described as 'hall-houses' were in fact residential spaces, that were once accompanied by a ground-floor medieval hall, likely built predominantly of timber and that these are now largely lost. The 'hallhouse' therefore was unlikely to have been a 'public' building in the medieval sense, and instead may have operated as a private space or residence - a medieval chamber. Rather than Ireland being an exception to the trends of medieval domestic planning visible in England and France, these results demonstrate similarities with the broader Norman world in the 13th century.

\section{THE LIVING SPACES OF SEIGNEURIAL CHAMBERS}

The internal arrangement of these medieval buildings has the potential to reveal how these spaces were used by the people who lived in them. The focus seems to have been at firstfloor level. If, as suggested above, these buildings contained the main residential space of a seigneurial household, this first floor must have catered to a wide spectrum of needs. One of the characteristics of a household is the division of space for different tasks or social situations. Although speculative, it is suggested here that the first-floor spaces of these Irish houses, which from now on are termed chambers, may have contained 'rooms'. Contemporary chambers in England contained original, upstanding internal stone divisions that separated the building into larger and smaller chambers such as at the well-known example of Boothby Pagnell. These 'rooms' are usually referred to as the 'inner chamber' and 'outer chamber' - these terms are employed here in recognition that similar layout is probable. The inner chamber typically contained access to a latrine and was only accessed from the outer chamber which typically contained a fireplace. In some Irish buildings, such as at Castlemagarret, a fireplace was situated in the inner chamber, but evidence for its occurrence in the outer chamber can be found at Dunmore and Tomdeely.

Original stone divisions simply do not survive within these seigneurial buildings in Ireland. A very small number of chambers contain masonry scars, which could be indications of the locations of former partitions. In others, late-medieval divisions, which appear to compliment the original design, may have fossilised the position of earlier partitions. The evidence, however, is sparse with just three buildings that have such features at first-floor level. Internal divisions do not survive because they were probably largely made of timber. Timber was widely used in the construction of medieval buildings and it was an integral part of stone buildings too. Beyond decorative elements it formed floors, roofs (or at least their trusses) and stairs. There is little research in Ireland on high medieval timber buildings or dealing with the traces timber fixtures and fittings may have left within surviving masonry and there is even less exploration of how putative timber partitions may have functioned as internal divisions. Such divisions could of 
course have been constructed with textiles such as wall hangings, curtains and screens, facilitating fluid and movable spaces within the first-floor chamber.

Although divisions of space may have been ephemeral, alongside masonry scars and the hints garnered from late-medieval divisions, further clues remain. In these buildings, as identified above, the latrine was typically situated in the furthest corner angle from the main entrance, diagonally opposed, or directly opposed, indicating that either the doorway or the latrine or both were likely screened from view. Latrines and fireplaces, where they survive are regularly placed close to each other and away from the main entrance, or they shared a wall, most commonly along the northern (colder) façade. Other intimations that can be used to reconstruct spatial divisions are the window embrasures. If these are grouped together, obviously spaced or set closer to one corner or another, they can offer indications of how the space may have been divided up.

A series of detailed descriptions are now used to underpin this argument for internal divisions of various kinds within these first-floor medieval chambers. The buildings used in this study continued to be occupied throughout the medieval period, in some cases long after the high medieval hall had ceased to act as an administrative and ceremonial centre. In the vast majority of buildings, there is substantial evidence for later inserted features, including windows, fireplaces and ground-floor entrances. Generally, these alterations were largely made without any great impact upon the original buildings. This attests to the suitability of these structures as residential spaces - their internal arrangements coupled with their architectural features rendered them highly versatile. Examples that have compelling evidence that they were once divided, or contain indications of late-medieval insertions, are labelled as 'differentiated' and account for 39 out of the total number of 47 that have substantive material remains. Those that do not contain any indication of divisions at first-floor level are described here as 'single chambers' - rooms that appear to have been undivided.

\section{DIFFERENTIATED}

Ballycurrin (19.8 m x $12 \mathrm{~m}$ ) is located in Co Mayo, which is situated in western Ireland in the province of Connacht. It is large rectangular two-storey building that was constructed $\mathrm{c}$ 1235-1260, and was later subject to alterations post-1500 (Fig 8). At some point in the past, the western section collapsed. As with all of the buildings in this paper, it is clear that the focal space was at first-floor level. The eastern section contains a group of four lancet-shaped windows set directly opposite each other, two in each of north and south walls. The north-eastern corner contains a dog-leg passage with plank centring that leads to a latrine which protrudes slightly outwards from the wall, like a shallow buttress. Despite the partial collapse of the western end it is most likely that this contained the main entrance, positioned opposite to the latrine. Little architectural detail remains in western area apart from a single ambry in the southern wall and the hint of a window embrasure further south along the same wall. Notwithstanding the loss of walling, it seems apparent that this area did not contain the provision for elaborate and symmetrical fenestration that is evident in the eastern section, and is rare across these chambers in general.

Unusually Ballycurrin contains a large octagonal pier that is original to the 13th-century building, and the function of which is uncertain. ${ }^{45}$ The pier rests slightly off centre towards the eastern end of the building. It is now incorporated into later medieval additions, including a pair of large barrel vaults at ground-floor level, as well as acting as a support for a stone partition at first-floor level. Given its octagonal shape, one might suggest it originally functioned as a large central hearth for the upper level. However, this is unlikely. The building has a large span and 
prior to the insertion of the vaults, it contained a wooden floor that would have required support. It is likely that an axial joist ran down the length of the building and it too would have needed reinforcement, a function performed by the octagonal pier. Although this does not fully preclude it acting as a base for a hearth, this seems unlikely, since there would have been timbers between the pier and the hearth.

With this is mind, an arrangement of the space may be tentatively proposed. There are clues within the formation of the window embrasures at first-floor level, where they are closely arranged within the eastern section and notably less present in the western section (although the ruined nature of this section needs to be acknowledged). Similarly, the latrine is accessed from the eastern section, and from comparative analysis the main entrance must have been located in opposition to latrine perhaps in the south-western corner. Returning to the octagonal pier, which is off-centre and now supports a later stone partition, it is possible to infer that the late-medieval stone partition may have replaced an earlier, similarly functioning wooden partition in the same location that used the stone pier in a similar manner. The latrine, used exclusively by the residents, must reflect the location of a more private space which contained well-appointed windows. The provision of fine windows in chambers, while rare across the Irish repertoire, was not unusual in medieval chambers in England or France. At Ballycurrin, it would also frame the inner chamber as a bright space which connected to a relatively poorly-lit western area. At night, the windows, shuttered against the cold, may have had pins or shafts of light escaping, which framed the building against the night sky.

Castlemagarret is a large two-storey rectangular building. The north-eastern and southeastern sections have fallen, but the remaining walls stand to full height and an inserted second floor is evident. At first-floor level, the shorter western wall contains a possible fireplace which is narrow and set into a rounded recess. Further north, close to the fireplace is a splayed roundheaded window embrasure with a cut-stone single light. The northern wall once contained three large window embrasures although the central example has been blocked. The westernmost of the three provides access to a latrine through the westernmost embrasure return. An ambry is located in the opposite return. Beside this embrasure, to the north, are a large masonry scar and the remains of an indentation (Fig 9).

In this instance, it is possible that the scar and indentation represent the former presence of a partition that separated the space into two unequal sized rooms. The architectural layout including the placement latrine at one end of the first-floor space indicates that this may have been the inner chamber. The small fireplace was also located here. Access to the latrine, through the return of the window embrasure beyond the scar suggests that the approach to this space could only be achieved from the smaller western section, which may have contained the inner chamber. By moving from an outer to an inner chamber, a person was moving towards more a more secluded and private space, heated by a small fireplace and with access to the latrine. Each opening may have contained a wooden door or heavy curtain, each signifying perhaps, a change in the expected social codes of behaviour of either the occupant or the visitor. The lighting at this particular junction would also have been different as indicated by the presence of the ambry close to the access to the latrine. Such spatial divisions, connected to public and private etiquette, may have been commonplace, and this kind of evidence can help the archaeologist pin-point and reconstruct these interior details (Fig 11).

There are six buildings in the dataset which contained an original third storey. In these buildings, it appears that the internal space was partitioned on a vertical, rather than horizontal, axis. Shrule, which exemplifies this form of division, is interesting as well because it has chamfered corners, a slightly protruding latrine chute, mural chambers and fireplaces. It was 
once the caput of a large territory and it has a recognised, associated deserted medieval settlement.

At Shrule, the first-floor entrance is located in the south-eastern corner, opposite the latrine which is accessed via a mural passage. This chute protruded externally and served latrines at both first and second-floor level. Each of these floors appears to have contained a potential fireplace. Furthermore, each floor is provisioned with unusual mural chambers. There are intricate patterns of access - the second floor is accessed from a mural stairs leading from the eastern return of the first-floor entrance, and the latrines are located at the end of long mural passages.

Which spaces served as the inner or the outer chambers, or the more or less private rooms, are difficult to identify. However, typically the upper floors of buildings are considered to be less accessible and therefore less public. Yet at Shrule a mural stairs leads to the second floor from the main entrance. This, however, may not be as accessible as it initially seems. On entering the first-floor space, if the door was thrown open into the chamber, it would have blocked this access route to the second-floor level. It is only possible to reach the second-floor once the door of the main entrance at first-floor level has been closed. The person entering the chamber must then turn around to face the now closed first-floor doorway before turning left to proceed up the mural stairs. This suggests that there were very particular ascribed patterns of movement throughout the building.

Lisbunny, was the caput of a large manor with an associated parish church, ${ }^{46}$ located close to Theobald de Walter's caput at Nenagh, Co Tipperary. At Lisbunny (Fig 11), there may have been a particular arrangement of 'rooms' which separated the upper level into two unequal sized spaces. The main entrance was located in the south-eastern corner, in the short wall. Beside this, in the southern corner, was a wooden spiral stair (now lost, although its scar remains), which appears to be largely contemporary. The stairwell exists in a slight protrusion in the eastern end of the south wall and there is no break in the masonry. This gave access from the first floor to basement level, and to the wall-walk which was later altered to contain a further level. It is not clear why access to the spaces above and below was important at this particular junction. If this was a contemporary feature, there may have been a small 'lobby' area where both the main entrance and the stairway were separated from the rest of the first-floor space. A fireplace and window are grouped together in the north-eastern corner, and two large openings are centrally placed in each the western and southern walls - the embrasure closest to the main entrance contains window seats (which are uncommon). It is likely that the northwestern opening led to a, now lost, machicolated latrine.

The placement of the windows as well as the fireplace and latrine indicate a deliberate arrangement of space (see Fig 6 for the fireplace). It is possible to speculate that the outer chamber comprised two windows in the south wall, as well as the fireplace and window along the north-eastern wall. A partition may have separated this area from the inner chamber which contained the latrine and a window in the west wall. A single aumbry is located close to the window at the south-eastern edge. The outer chamber contained the fireplace and a large window which faced east. This would have caught the rising sun and been naturally well lit throughout the day. The space would have been heated by the fire in the evening when the south-western space would have been lit by the setting sun. Once the natural light was gone, a lamp or candle would have been provided, set on within the aumbry to light the space removed from the fire. Along the southern wall are two well-appointed windows, one of which contained windows seats from which the associated parish church could be viewed. At Lisbunny, access to 
the inner 'room' would have been a circuit, accessed by passing from the entrance across the main or outer chamber and passing by the fireplace.

\section{SINGLE-CHAMBER FORMAT}

Only ten buildings had no evidence of internal partitions of any kind, beyond a latrine screen or doorway at first-floor level, such as Kilskeagh in Co Galway (Fig 12), Castle Carra, Co Antrim and Glanworth, Co Cork. These buildings appear to comprise an upper level with a single 'room' raised over a basement with a very small internal living space. Due to their small size and their architectural layout, it seems unlikely that these once hosted a major partition. The upper level usually contains a machicolated latrine that was accessed through a slightly skewed passage, designed with a slight angle presumably for privacy, containment of odours, or to facilitate the hanging of a curtain as a sort of door. The main entrance is often directly opposite or diagonally opposed to the latrine, as seen in the previous examples. The space is quite well-lit and usually contains windows set in a large embrasure in each wall. A number of aumbries or lamp-rests are frequently found throughout the chamber at both upper level and basement. In some cases, the basement may have had independent external access as at Kilskeagh.

These single chambers share a small size and the absence of any evidence for major internal divisions at first-floor level. They do not share any chronological pattern: Kilskeagh postdates 1235 and Castle Carra is reputed to date to 1301, whereas Glanworth may pre-date 1200. There is also limited geographical correlation: they occur in distant and apparently unrelated locations. However, Kilskeagh and Castle Carra are likely to have been of a similar status, falling below the rank of manor, and may be non-seigneurial residences of landowning individuals below the level of lords, unlike Glanworth which belonged to a high-ranking lord and was the caput of the cantred of Fermoy and situated within a larger complex. ${ }^{47}$

\section{UNDERSTANDING SPACE IN THE CHAMBER}

Current post-Enlightenment concepts of individual privacy differ greatly from those of medieval people who viewed it as a withdrawal from the public sphere and places such as the medieval hall. ${ }^{48}$ Architecturally, the hall embodied 'publicness' by providing a designated formal space within which elaborate social codes were enacted and the seigneurial duties and obligations of elites were conducted. As has already been explored above, the chamber, unlike the hall, was a residence and therefore not a formalised ceremonial and administrative centre. Despite the chamber operating as the corollary of the medieval hall, it is imperative to avoid projecting a false public / private dichotomy onto these residences. Indeed, both contextual and architectural analysis shows the complexities of the ways these medieval chambers were occupied. Most of the first-floor spaces were probably partitioned; divided into two unequal sized areas - a large room that sometimes contained a fireplace and was accessed through the main first-floor entrance, and a second smaller room that typically had access to a latrine and sometimes contained a fireplace. The presence of two 'rooms' could have permitted greater and lesser degrees of privacy, perhaps even at times the two spaces could have been used independently and thus, it is incorrect to view the chamber as either a fully 'public' or 'private' space. Instead, the larger space can be envisaged as a kind of living room or a private space that might sometimes be used in a public manner. The chamber was socially exclusive and likely only accessible to favoured members of the familia or perhaps socially important guests. ${ }^{49}$ It was, after all, the lord and lady's personal space and would have suited their needs. 
This article has made use of a rich dataset of surviving structures in Ireland, and via close analysis of these buildings, and consideration of their immediate and broader landscape contexts, a convincing synergy is suggested with similar structures in Britain, in terms of plan and building style. The 'upper-hall' model has been contested in England for over two decades. It is now generally accepted that buildings formerly considered upper-halls are chambers. ${ }^{50}$ However, this interpretation still remains contentious in Ireland and Scotland. ${ }^{51}$. where others continue to view the 'hall-house' as both a residence and a hall. ${ }^{52}$ This is at least partially related to idea that there were 'exceptional' differences between England and Ireland, where it is believed that lots of 'first-floor halls' remained in use long after their English counterparts. ${ }^{53}$ Yet this study shows that the Irish 'hall-house' is not exceptional, in fact it seems to bear close similarity to the English and French medieval domestic residence and chambers. Just like those it occurs as a complex of seigneurial buildings often set within an enclosure. The reinterpretation of these structures provided here has enabled the reconstruction of aspects of the architecture, furnishings and functionality of medieval domestic and private space in the Irish Middle Ages. This helps us better understand medieval buildings in terms of how people created, used and experienced them in the past.

\section{ACKNOWLEDGEMENTS}

This research was conducted as part of a broader PhD project completed at University College Dublin, School of Archaeology kindly funded by the Irish Research Council. The article has benefitted from the expertise and input of Professor Tadhg O'Keeffe, Dr Rob Sands, Conor McDermott and Dr Neil Carlin. Thanks to Dr Seamús Ó Murchú for his assistance in map making. I would like to thank the landowners who gave permission for access for the surveys.

\section{BIBLIOGRAPHY}

Austin, D 1998, 'Private and public: an archaeological consideration of things', in Hundsbichler, Jaritz andKühtreiber (eds), Die Vielfalt der Dinge : neue Wege zur Analyse mittelalterlicher Sachkultur, Vienna: Austrian Academy of Sciences, 163-206.

Barry, T 1987, The Archaeology of Medieval Ireland. London: Routledge.

Blair, J 1999, 'Hall and chamber: English domestic planning 1000-1250', in Meirion-Jones and Jones, 1-24.

Carrigan, W 1905, The History and Antiquities of the Diocese of Ossory, volume iv, Dublin: Sealy, Bryers and Walker.

Dempsey, K 2014, Recent Revelations in Medieval Co. Roscommon, Report for Roscommon County Council.

Dempsey, K 2016, 'Rectangular Chamber-Towers and their Medieval Halls: A Recent Look at the Buildings Formerly Described as "Hall-Houses"...', Château Gaillard 27, Publication du CRAHM - Presses Universitaires de Caen, 113-119.

Eadie, G 2010, A New Approach to Identifying Function in Castles: A Study of Tower Houses in Ireland, (unpub PhD thesis, Queen's University Belfast).

Eadie, G 2015a, "Know you that serving folk be of three kinds'; Irish towers and the familia', in Oram, 174-88.

Eadie, G 2015b, 'Identifying functions in castles: a study of tower houses in Ireland', in Oram, 218. 
Faulkner, P A 1958, 'Domestic planning from the twelfth to the fourteenth centuries', Archaeol J 115:1, 150-183.

Faulkner, P A 1963, 'Castle planning in the fourteenth century', Archaeol J 120:1, 215-35.

Finan, T 2010 'The hall house at Kilteasheen, Co. Roscommon, Ireland', Chateau Gaillard: Etudes de Catellogie Medievale 24, Stirling. Publication du CRAHM - Presses Universitaires de Caen

Finan, T 2015, 'Hall houses, Church, and State in thirteenth-century Roscommon: The origins of the Irish tower house', in R Oram R (ed), A House That Thieves Might Knock At'. Tower Studies, 1 \& 2, Donington: Shaun Tyas, pp. 231-257 Gardiner, M 2008, 'Buttery and pantry and their antecedents: ideas and architecture in the English medieval house', in M Kowaleski and P J P Goldberg (eds), Medieval Domesticity, Cambridge: Cambridge University Press, 37-65.

Gardiner, M 2015, 'Conceptions of domestic space in the long term - the example of the English medieval hall', in M S Kristiansen, E Roesdahl and J Graham-Campbell (eds), Medieval Archaeology in Scandinavia and Beyond: History, Trends and Tomorrow, Aarhus: Aarhus University Press, 313-33.

Harris, R and Impey, E 2002, 'Boothby Pagnall revisited,' in Meirion-Jones, Impey and Jones, 21134.

Hill, N 2013, 'Hall and chambers: Oakham Castle reconsidered', Antiq J 93, 163-216.

Holland, P 1987/8, 'The Anglo-Normans in Co. Galway: The process of colonization', J Galway Archaeol Hist Soc 41, 73-89.

Holland, P 1997, 'The Anglo-Norman landscape in County Galway; land-holdings, castles and settlements', J Galway Archaeol Hist Soc 49, 159-93.

Impey, E 1999a, 'The seigneurial residence in Normandy, 1125-1225: an Anglo-Norman tradition?' Med Archael 43:1, 45-73.

Impey, E 1999b, 'Seigneurial domestic architecture in Normandy, 1050-1350', in Meirion-Jones and Jones, 82-120.

Johnson, M 2002, Behind the Castle Gate: from Medieval to Renaissance, London: Routledge.

MacCotter, P 2008, Medieval Ireland: territorial, political and economic divisions, Dublin: Four Courts.

Meirion-Jones, G, Impey, E and Jones, M (eds) 2002, The Seigneurial Residence in Western Europe AD c800-1600, Brit Archaeol Rep Int Ser 1088.

Meirion-Jones, G and Jones, M (eds) 1993, Manorial Domestic Buildings in England and Northern France, Soc Antiq London Occas Pap New Ser 15.

McNeill, T 1992, 'The origins of tower houses', Archaeol Ireland 6:1, 13-14.

McNeill, T 1997, Castles in Ireland, Feudal Power in a Gaelic World, London: Routledge.

McNeill, T 2002, 'The gap below the castle in Ireland', in Meirion-Jones, Impey and Jones, 45-6.

O'Brien, C 1993/4, 'A 13th-century hall house at Clohaskin, Co. Limerick', North Munster Archaeol J 35, 104-6.

O'Conor, K 1998, The Archaeology of Medieval Rural Settlement in Ireland, Roy Ir Acad Discovery Program Monogr 3.

O'Conor, K 2002, 'Motte castles in Ireland: permanent fortresses, residences and manorial centre' Château Gaillard, Château Gaillard 20, Publication du CRAHM - Presses Universitaires de Caen 20 :173-1820'Conor, K and Naessens, P 2015, 'Temple House: from Templar castle to new English mansion', in M Brown and C Ó Clabaigh (eds), Soldiers of Christ: The Knights Templar and Knights Hospitaller in Medieval Ireland, Dublin: Four Courts Press, 124-51. 
O'Keeffe, T 2013/2014, 'Halls, 'hall-houses' and tower-houses in medieval Ireland: disentangling the needlessly entangled', Castle Stud Group J 27, 298-307.

O'Keeffe, T 2014, 'Building lordship in thirteenth-century Ireland: the donjon of Coonagh Castle, Co. Limerick', J Roy Soc Antiq Ireland 141, 91-127.

O'Keeffe, T 2015, Medieval Irish Buildings 1100-1600, Dublin: Four Courts Press.

Oram, R (ed) 2015, 'A House Such as Thieves Might Knock at', proceedings of the 2010 Stirling and 2011 Dundee Conferences on 'The tower as lordly residence' and 'The tower and the household', Donington: Shaun Tyas.

Quiney, A 1999, 'Hall or chamber? That is the question. The use of rooms in post-conquest houses', Architect Hist 42, 24-46.

Ronnes, H 2004, “A solitary place of retreat': Renaissance privacy and Irish architecture', Internat $J$ Hist Archaeol 8:2, 101-117.

Sherlock, R 2010, 'The evolution of the Irish tower-house as a domestic space', Proc Roy Ir Acad 111:C, 115-140.

Sherlock, R 2014, 'Hall houses; tower houses; Bunratty Castle; Blarney Castle; Dunsoghly Castle; Clara Castle', in R Moss (ed) Art and Architecture of Ireland, I: Medieval Art and Architecture, Dublin: Royal Irish Academy, 352-60.

Sherlock, R 2015, 'The spatial dynamic of the Irish tower house hall', in V McAlister and T Barry (eds), Space and Settlement in Medieval Ireland, Dublin: Four Courts Press, 86-109.

Stell, G 2014/15, 'Scottish "hall-houses": the origins and development of a modern castellological concept', Castle Stud Group J 28, 134-9.

Sweetman, D 1992, 'Dating Irish castles', Archaeol Ireland 6:4, 8-9.

Sweetman, D 1999, The Medieval Castles of Ireland, Cork: Collins Press.

Sweetman, D 2004, 'The origin and development of the tower-house in Ireland' in J Ludlow and N Jameson (eds), Medieval Ireland: The Barryscourt Lectures 1-10, Kinsale: Gandon Editions, 261-87.

Thompson, M W 1995, The Medieval Hall: the Basis of Secular Domestic Life, 600-1600 AD, Aldershot: Scolar Press.

Webb, D 2007, Privacy and Solitude in the Middle Ages, London: Hambledon Continuum. White, N B (ed) 1932, Dublin: Irish Manuscripts Commission.

Wood, M 1965, The English Mediaeval House, London: Ferndale Editions.

\section{Abbreviations}

BAR British Archaeological Reports

CDI Calendar of Documents Relating to Ireland

RCAHMS Royal Commission on the Ancient and Historical Monuments of Scotland

\section{CAPTIONS}

FIG 1

Annaghkeen, Co Galway. Facing north-west. View of first-floor doorway and base-batter. This is often cited as a classic Irish 'hall-house'. Image by Karen Dempsey

FIG 2 
Distribution of the seigneurial buildings identified and discussed in this study, including those classified as 'hall-houses'. Map by Seamús Ó Murchú and Karen Dempsey

FIG 3

Dunmore (Co Galway) and Kinlough (Co Mayo). Both walls were augmented. The former 13thcentury crennellations are still visible in the upper walling of Kinlough.

FIG 4

A selection of buildings with 'chamfered corners' (clockwise from top left): Clohaskin;

Castlemagarret; Castlemagarret (chamfer detail); Grenan; and Tomdeely. Images by Karen

Dempsey and Conor McDermott

FIG 5

A selection of latrine types (clockwise from top left): Machicolated latrine (ruined), Ballisnahyny; service tower, Cramps' Castle, Co Tipperary; 'robbed out' latrine chute, Shrule; 'buttress' latrine, service or latrine tower, Kindlestown; buttress latrine, Castle Carra, Co Mayo; 'robbed out' latrine chute, Fartamore, Co Galway. Images by Karen Dempsey and Conor McDermott

FIG 6

A selection of fireplaces from seigneurial residences of varying ranks, from low- to high-status (clockwise from the top left): Castlemagarret; Lisbunny; Shrule; Coonagh; and Dunmore. Images by Karen Dempsey and Conor McDermott

FIG 7

Results of geophysical survey at Annaghkeen, Co Galway; Shrule and Ballisnahyny, Co Mayo. Image by Conor McDermott and Karen Dempsey

FIG 8

Sketch plan of Ballycurrin, Co Mayo. Note octagonal pier. Image by Karen Dempsey

FIG 9

Castlemagarret, Co Mayo, facing north-east. Interior view of latrine passage and masonry scar indicating a former partition. Image by Karen Dempsey

FIG 10

Sketch plan of Shrule, Co Mayo. Note the unusual mural chambers as well as the two floors of residential space. Image by Karen Dempsey

FIG 11

Re-imagining spatial divisions: interpretations of the former divisions of the first-floor spaces at Lisbunny and Castlemagarret (sketch plans). Image by Conor McDermott and Karen Dempsey

FIG 12

Sketch plan of Kilskeagh, Co Galway. Image by Karen Dempsey

${ }^{1}$ Karen Dempsey, 67 Adelaide Road, Dublin 2, Ireland. karendempsey@gmail.com. 
${ }^{2}$ See, for example, McNeill 1992, 13-14; 1997; Sweetman 1992; 1999; 2004; Sherlock 2010; 2014; 2015; Finan 2015; O'Conor and Naessens 2015.

${ }^{3}$ McNeill 1997, 154; Sweetman 1999, 89; Sherlock 2015; Finan 2010, 80. Each author uses the term 'hall-house' while also suggesting the building was a residence. McNeill explicitly states 'They are, however, clearly residential in nature. Their main purpose is to provide a well-built and impressive hall' $(1997,54)$.

${ }^{4}$ McNeill 1997, 149; 2002, 45-6; Sweetman 1999, 89.

${ }_{6}^{5}$ McNeill 1992, 13-14.

${ }^{6}$ Sweetman 1999, 89-105.

${ }^{7}$ See Sherlock 2010; McNeill 1992; 1997, 14-15 and Sweetman 1999, 89-105.

${ }^{8}$ O'Keeffe 2013/14.

${ }^{9}$ Formerly of RCAHMS, see Stell 2014/15.

${ }^{10}$ See Gillian Eadie 2010, 69-75; 2015a, 2015b.

${ }^{11}$ See Faulker 1958, 1963 for earlier work and Gardiner 2008 for more recent scholarship on medieval halls.

12 Blair 1999.

${ }^{13}$ For the first-floor hall interpretation see Wood 1965, and for the later re-interpretation see Harris and Impey 2002.

${ }^{14} \mathrm{Ibid}$.

${ }^{15}$ See Impey (1999a, 1999b) for a discussion on the similarities in domestic architecture before 1225 in England and France, and the subsequent differences after this period.

${ }^{16}$ See Holland 1987/8, 73-89. Sweetman 1999, 104, believed that 'hall-houses' originated in the west and spread east.

${ }^{17}$ Perhaps Baggotrath in the city-centre of Dublin on Baggot Street, which was cleared during the 17th century may be an example.

${ }^{18}$ McNeill 1997, 149.

${ }^{19}$ The 'pilaster' group has been discussed in brief by O'Keeffe (2014) in his paper on the Anglo-Norman castle at Coonagh, Co Limerick.

${ }^{20} \mathrm{lbid}$.

${ }^{21}$ Wood 1965, 261.

${ }^{22}$ Coonagh was never considered a 'hall-house', it had been labelled as a tower-house by the National Monuments Service during the Archaeological Survey of Ireland. However, it is the exemplar of a high-status, medieval chamber, and formed part of this study for this reason.

${ }^{23}$ MacCotter 2008, 135:

${ }^{24}$ Wood 1965, 262.

${ }^{25} \mathrm{Ibid}$.

${ }^{26}$ See Johnson 2002, 78; Gardiner 2008; 2015.

${ }^{27}$ Wood 1965, 49.

${ }^{28}$ See Austin 1998; Webb 2007; Ronnes 2004.

${ }^{29}$ Thompson 1995, 5.

${ }^{30}$ See Blair 1999; Impey and Harris 2002; O'Keeffe 2013/14.

${ }^{31}$ Barry 1987, 186.

${ }^{32}$ See O'Conor 1998, 26-39, for details on manorial centres such as Inch, Co Tipperary; Cloncurry and Ryban, Co Kildare; and Dunfert and Lough Mearns, Co Kilkenny. See also O'Conor 2002 for further discussion on associated buildings.

${ }^{33}$ McNeill 2002.

${ }^{34}$ McNeill 2002, 46.

${ }^{35}$ O'Keeffe 2013/14..

${ }^{36}$ O'Conor 1998, 38.

37 See Holland 1997, and McNeill 1997.

${ }^{38}$ With thanks to Roscommon County Heritage Bursary for special funding to investigate four earthworks sites in medieval Roscommon.. See Dempsey 2014.

${ }^{39}$ Castlemore and Castlesampson are part of another research paper and therefore will not be discussed in detail here.

${ }^{40}$ Impey and Harris 2002.

${ }^{41}$ McNeill 2002.

${ }^{42}$ Dempsey 2014.

${ }^{43}$ Contra Caimin O'Brien 1993/4, 104-6. This is likely an original feature. 
${ }^{44}$ Carrigan 1905, volume iv, 266-7. Grenan Castle is a large, high-status chamber that once belonged to Thomas fitz Thomas, a steward of William Marshall. It contains ornate features, such as a quatrefoil window, as well as imported Dundry stone.

45 There is an example of a similar pier at the complex of Jacobstow, Cornwall, Blair 1999, 3.

${ }^{46}$ The associated church is listed in the Papal Taxation of 1302 as worth 6 marks (CDI v, 302).

47 MacCotter 2008, 30-3.

${ }^{48}$ Ronnes 2004; Eadie 2010; 2015a, 2015b.

49 Johnson 2002, 80.

50 Blair 1999; Impey and Harris 2002; Hill 2013; but not Quiney 1999.

${ }^{51}$ Dempsey 2016; O’Keeffe 2013; Stell 2015.

52 Finan 2013; Sherlock 2014; 2015.

53 Ibid; O'Conor and Naessens 2015. 